Article

\title{
The Effects of Calcium Ions on the Flotation of Sillimanite Using Dodecylammonium Chloride
}

\author{
Zhijie Chen ${ }^{1}$, Zijie Ren ${ }^{1,2, *}$, Huimin Gao ${ }^{1,2}$, Jia Lu ${ }^{1}$, Junxun Jin ${ }^{1}$ and Fanfei Min ${ }^{3}$ \\ 1 School of Resources and Environmental Engineering, Wuhan University of Technology, Wuhan 430070, \\ China; czjczj@whut.edu.cn (Z.C.); gaohuimin1958@126.com (H.G.); lujiapeter@163.com (J.L.); \\ jinjunxun@whut.edu.cn (J.J.) \\ 2 Hubei Key Laboratory of Mineral Resources Processing and Environment, Wuhan University of Technology, \\ Wuhan 430070, China \\ 3 School of Materials Science and Engineering, Anhui University of Science and Technology, Huainan 232001, \\ China; ffmin@aust.edu.cn \\ * Correspondence: renzijie@whut.edu.cn; Tel.: +86-27-8788-2128
}

Academic Editor: William Skinner

Received: 3 November 2016; Accepted: 16 February 2017; Published: 17 February 2017

\begin{abstract}
The effects of $\mathrm{Ca}^{2+}$ ions on the flotation of sillimanite using dodecylammonium chloride as a collector were investigated by micro-flotation tests, zeta potential measurements, solution chemistry analysis and molecular dynamics (MD) simulation. The micro-flotation results indicated that $\mathrm{Ca}^{2+}$ ions remarkably inhibit the flotation of sillimanite in the $\mathrm{pH}$ range of 2.0-9.0. The point of zero charge (PZC) of sillimanite changed from 5.4 to 6.1 with the addition of $\mathrm{Ca}^{2+}$ ions. Meanwhile, the calculated concentration of $\mathrm{RNH}_{3}{ }^{+}$in the sillimanite interface layer decreased in the presence of $\mathrm{Ca}^{2+}$ ions. The results of MD simulation revealed that $\mathrm{Ca}^{2+}$ ions have strong binding energy with the sillimanite (010) surface, and the binding energy of $\mathrm{RNH}_{3}{ }^{+}$with sillimanite (010) surface reduced in the presence of $\mathrm{Ca}^{2+}$ ions. The conclusions drawn from the computations are in good agreement with the experimental results.
\end{abstract}

Keywords: calcium ions; dodecylammonium chloride; sillimanite; flotation; solution chemistry; molecular dynamics (MD) simulation

\section{Introduction}

Sillimanite is an alumino-silicate mineral with a chain structure, which shares the same chemical formula $\mathrm{Al}_{2} \mathrm{SiO}_{5}$ with kyanite and andalusite. The bulk lattice structure of sillimanite is shown in Figure 1. As a kind of refractory raw material, sillimanite is widely used in the linings of blast furnaces, the rotary kilns in cement manufacturing and general kilns of lime production [1-6]. Today, it is of great necessity to produce high quality sillimanite as industrial needs of high grade sillimanite are gradually increasing.

As a non-conducting and non-magnetic mineral, sillimanite needs to be separated from other gangue minerals by flotation [4]. Dodecylammonium chloride (a kind of cationic collector) has been extensively used in this situation $[7,8]$. Previous research has showed that the unavoidable metal ions in process water, such as $\mathrm{Ca}^{2+}$ and $\mathrm{Mg}^{2+}$ ions, affect the flotation of silicate minerals significantly [9-14]. Lu et al. [15] described the depression effects of $\mathrm{Ca}^{2+}$ ions on andalusite, and the results showed that both $\mathrm{Ca}^{2+}$ ions and $[\mathrm{CaOH}]^{+}$could depress the flotation of andalusite. Liu et al. [13] investigated the effects of $\mathrm{Ca}^{2+}$ and $\mathrm{Mg}^{2+}$ ions on the flotation of spodumene with sodium oleate as the collector. They found that the hydroxy complexes $\left([\mathrm{CaOH}]^{+}\right.$and $\left.[\mathrm{MgOH}]^{+}\right)$and precipitates $\left(\mathrm{Ca}(\mathrm{OH})_{2}\right.$ and $\left.\mathrm{Mg}(\mathrm{OH})_{2}\right)$ contributed to the formation of oleate complexes, thus the amount of collector adsorption and the floatability of spodumene increased. A similar result was reported by Yu et al. [12] through a density 
functional theory (DFT) calculation. They pronounced that the precipitation of calcium hydroxide on the spodumene surface was an effective process to activate the flotation of spodumene. Demir et al. [9] researched the effects of $\mathrm{Ca}^{2+}$ ions on the separation of Na-feldspar from K-feldspar. In their study, $\mathrm{Ca}^{2+}$ ions exhibited complex and interesting features of adsorption and ion exchange patterns, which proved beneficial in the separation of individual feldspar minerals. In the flotation of microcline, quartz as the gangue could be activated in the presence of $\mathrm{Ca}^{2+}$ and $\mathrm{Mg}^{2+}$ ions, but microcline did not respond to flotation with these cations [16]. Burdukova et al. [17] concluded that the presence of calcium ions greatly enhanced the adsorption density of carboxymethyl cellulose on talc, which was attributed to the increased concentration of $[\mathrm{CaOH}]^{+}$on the mineral surface as well as the increased amount of coiling of the carboxymethyl cellulose macromolecules due to their reaction with $\mathrm{Ca}^{2+}$ ions.

Although the flotation of silicates with $\mathrm{Ca}^{2+}$ ions as the activator in the presence of sodium oleatehas been well researched, studies on the inhibition mechanism of $\mathrm{Ca}^{2+}$ ions on silicates with dodecylammonium chloride as the collector are limited. In the current work, the effects of $\mathrm{Ca}^{2+}$ ions on the flotation behavior of sillimanite were examined by pure mineral micro-flotation tests. The zeta potential analysis was carried out to reveal the charge changing on the mineral surface, with a molecular dynamics simulation applied to explain the experimental data at a molecular level, in an attempt to explain the mechanisms of the depression of $\mathrm{Ca}^{2+}$ ions on sillimanite.

\section{Materials and Methods}

\subsection{Materials and Reagents}

High grade sillimanite samples were obtained from Hebei Province, China. The samples were crushed and ground with an agate mortar, then sieved to obtain a particle size of $0.105-0.074 \mathrm{~mm}$ for micro-flotation tests before being washed with deionized water. The prepared samples were examined via a chemical method with a X-ray Fluorescence (XRF) spectrometer (Axios advanced, PAN Alytical B.V., Almelo, The Netherlands), and phase-examined using a powder X-ray diffractometer (XRD, D/Max-IIIA, Rigaku, Tokyo, Japan) with monochromatic $\mathrm{Cu}$ K $\alpha$ radiation in $5^{\circ}-80^{\circ}$ at a rate of $0.02^{\circ} / \mathrm{s}$. The results are shown in Table 1 and Figure 2, respectively. According to the results of the XRF and XRD analyses, the grade of sillimanite was approximately $95 \%$, and the main impurity was quartz (around 2.5\%).

Dodecylammonium chloride (DAC) was employed as the cationic collector for the flotation of sillimanite. Calcium chloride $\left(\mathrm{CaCl}_{2}\right)$ was purchased from the Sinopharm Chemical Reagent Co., Ltd. (Shanghai, China). Hydrochloric acid $(\mathrm{HCl})$ and sodium hydroxide $(\mathrm{NaOH})$ were prepared as one percent solutions for the $\mathrm{pH}$ adjustment of the slurry. The $\mathrm{pH}$ of the slurry was monitored with a RPB10 pH meter (Ruosull Technology Co., Ltd., Shanghai, China). All chemicals were of analytical grade, and deionized water with a resistivity value of $18.25 \mathrm{M} \Omega \cdot \mathrm{cm}$ was used in all experiments.

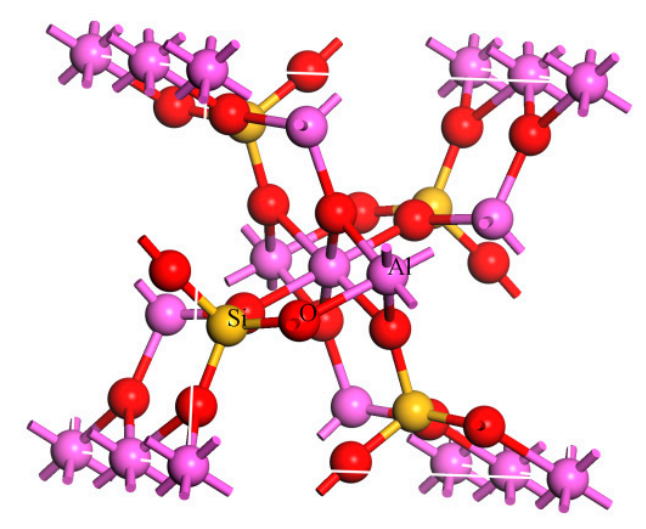

Figure 1. Bulk lattice structure of sillimanite (Atom color: pink $=\mathrm{Al}$, red $=\mathrm{O}$, yellow $=\mathrm{Si}$ ). 


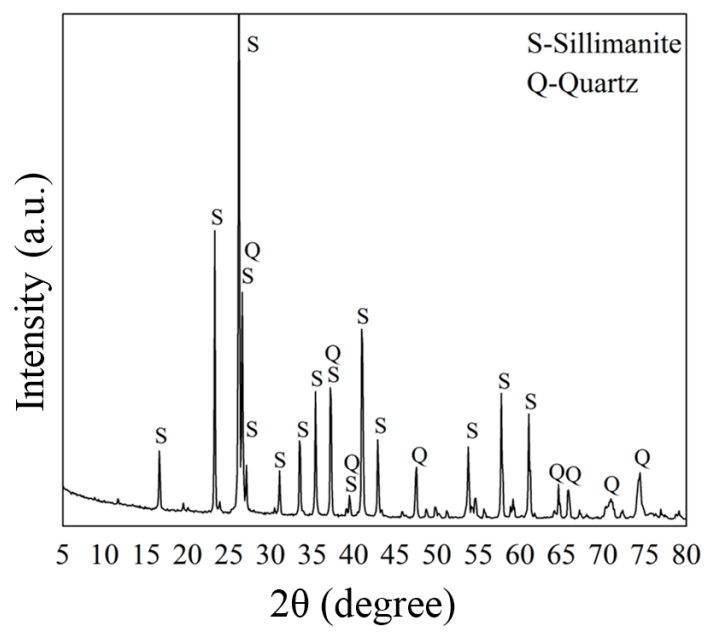

Figure 2. X-ray diffractometer (XRD) spectra of the sillimanite sample.

Table 1. The chemical composition of the sillimanite sample.

\begin{tabular}{cccccccccccc}
\hline Composition & $\mathrm{SiO}_{2}$ & $\mathrm{Al}_{2} \mathrm{O}_{3}$ & $\mathrm{CaO}$ & $\mathrm{Fe}_{2} \mathrm{O}_{3}$ & $\mathrm{TiO}_{2}$ & $\mathbf{K}_{2} \mathrm{O}$ & $\mathrm{ZrO}_{2}$ & $\mathrm{Cr}_{2} \mathrm{O}_{3}$ & $\mathbf{V}_{2} \mathrm{O}_{5}$ & $\mathrm{MoO}_{3}$ & Ignition Loss \\
\hline Content (\%) & 38.09 & 59.85 & 0.08 & 0.27 & 0.13 & 0.02 & 0.59 & 0.07 & 0.14 & 0.08 & 0.68 \\
\hline
\end{tabular}

\subsection{Micro-Flotation Experiments}

The micro-flotation experiments were conducted in a RK/FGC-35 hitch groove flotation cell (Wuhan Rock Crush \& Grand Equipment manufacture Co. Ltd., Wuhan, China). The pure mineral particles (two grams) were placed into a Plexiglas cell, which was then filled with $30 \mathrm{~mL}$ of deionized water. The pulp was continuously stirred for two minutes using a $\mathrm{pH}$ regulator, two minutes with the depressor, and two minutes with the collector at $1500 \mathrm{rpm}$ of agitation. The $\mathrm{pH}$ of the slurry was monitored before the flotation with a RPB10 pH meter, and flotation was conducted for five minutes. The floated and tailing fractions were collected separately and dried, then weighed for calculating recovery. All of the flotation tests were completed three times, and the average recovery and the standard deviation were reported.

\subsection{Zeta Potential Tests}

Zeta potential measurements were carried out using a 90 Plus Zeta Size Analyzer (Brookhaven Instruments Corporation, Holtsville, NY, USA). The particle size of the powder was ground finer than two micron for zeta potential tests. Suspensions (0.01\% mass fraction) with $1.00 \times 10^{-3} \mathrm{M} \mathrm{KCl}$ solution were dispersed in a beaker, then magnetically stirred for $15 \mathrm{~min}$ with and without $\mathrm{Ca}^{2+}$ ions at various $\mathrm{pH}$ levels. After one hour of settling, the $\mathrm{pH}$ value of the suspension was measured and the supernatant was obtained for Zeta-potential measurements. The measurements were performed at about $25^{\circ} \mathrm{C}$. Each sample was measured three times.

\subsection{Computational Methods}

All calculations were undertaken using the Material Studio 6.0 package (Accelrys Inc., San Diego, CA, USA). The Cambridge Sequential Total Energy Package (CASTEP) module was adopted to optimize the structure of sillimanite and adsorbates. For the sillimanite unit cell, the optimization parameters were set as follows: the function was GGA + PBE, $k$-point set was $3 \times 3 \times 4$, and the custom energy cutoff was $340 \mathrm{eV}$. The dispersion-corrected density functional theory (DFT-D) correction was adopted [18]. The threshold values for the convergence criteria were $2.00 \times 10^{-3} \AA$ as maximum displacement, $0.05 \mathrm{eV} / \AA$ as maximum force, $0.1 \mathrm{GPa}$ as maximum stress, $2.0 \times 10^{-5} \mathrm{eV} / \mathrm{atom}$ as energy, and $1.0 \times 10^{-6} \mathrm{eV} /$ atom as the self-consistent field tolerance. In the geometric optimization 
for bulk sillimanite, all the atoms and unit cell parameters were relaxed. The lattice optimization results were $a=7.57 \AA, b=7.80 \AA, c=5.81 \AA, \alpha=90^{\circ}, \beta=90^{\circ}, \gamma=90^{\circ}$, where the predicted lattice parameters were in reasonable agreement with those reported [19]. Next, a 2D periodic surface cell was created from the unit cell of the sillimanite at the complete cleavage plane (010) [6], and then optimized in the same way. The optimization of the $\mathrm{Ca}, \mathrm{RNH}_{3}(R=12)$ and water molecules were calculated in a $30.00 \AA \times 30.00 \AA \times 30.00 \AA$ cubic cell, and the optimizations were performed at the gamma point in the Brillouin zone. The other optimization parameters were the same as the primitive unit cell optimization. According to the molecule charged situation, the charge was chosen with $\mathrm{Ca}$ as $+2, \mathrm{RNH}_{3}$ as +1 .

The condensed-phase optimized molecular potentials for atomistic simulation studies (COMPASS) force field was employed in this work, and has been widely used in similar research $[6,20]$. The COMPASS force field can accurately predict structural, conformational, vibrational, cohesive and thermophysical properties for a broad coverage of molecules in isolation and in condensed phases under a wide scope of pressures and temperatures [21]. The expression of the COMPASS force field is detailed in [6].

A Forcite module was employed to calculate the adsorption energy. A periodic supercell $(34.86 \AA \times 37.59 \AA \times 33.72 \AA)$ with a $40 \AA$ vacuum along the $c$-axis was used. $\mathrm{Ca}, \mathrm{RNH}_{3}$ and water molecules worked as the adsorbate, and sillimanite worked as an adsorbent. The input structure of the adsorbate-sillimanite (010) surface complex was created with molecular graphics tools, and the geometry optimization of the system of adsorbate-sillimanite was conducted using the Smart Minimizer in the COMPASS force field $[6,20]$. The convergence criteria for the energy, force and displacement were set at $1.00 \times 10^{-4} \mathrm{kcal} / \mathrm{mol}, 5.00 \times 10^{-3} \mathrm{kcal} /\left(\mathrm{mol} \cdot \AA^{2}\right)$ and $5.00 \times 10^{-5} \AA$, respectively. The atoms at the top four layers and adsorbates were allowed to relax and the rest of atoms were constrained during the minimizations as only the atoms in the top several layers have interactions with adsorbate molecules [21]. Several initial conformations were assessed to locate the minimum energy conformation of adsorbates at the sillimanite (010) surface. Next, MD simulations were run using a canonical ensemble (NVT) [6,22] at $298.0 \mathrm{~K}$ with the time step of one femtosecond, and the total run length was $500 \mathrm{ps}$. As periodic boundary conditions were used in this study, the NVT ensemble provided the advantage of less perturbation of the trajectory, owing to the absence of coupling to a pressure bath [23]. During the MD simulations, the temperature was controlled with a Nose method and an atom based direct cut off (12.50 $\mathrm{A})$ method was employed to calculate both electrostatic interactions and van der Waals [24-26]. As the mineral surface was minimized in an earlier step, the entire surface atoms were constrained during dynamics $[22,27,28]$.

The aqueous environment was not included explicitly in the simulations; however, the interaction energy of a water molecule with a sillimanite (010) surface was computed and compared with other adsorbates-sillimanite interaction energies [6,29-31].

The interaction energy could be calculated using Equation (1) [32]:

$$
E_{i}=\frac{E_{\text {complex }}-\left(E_{\text {surface }}+E_{\text {adsorbates }}\right)}{n}
$$

where $E_{\text {complex }}$ is the total energy of the optimized adsorbates-sillimanite complex; $E_{\text {adsorbates }}$ is the energies of $n$ adsorbates; and $E_{\text {surface }}$ is the energy of the sillimanite (010) surface. The number of the adsorbates is $n$, and all the number of the adsorbates in all systems was one in this study.

Binding energy was defined to be the negative value of interaction energy $[20,25,33]$, namely:

$$
E_{\mathrm{b}}=-E_{\mathrm{i}}
$$

The more positive the magnitude of binding energy shown, the more favorable the interactions between the sillimanite (010) surface and the adsorbate. Hence, the magnitude of binding energy is an 
excellent measure of the relative efficiency of the interaction of different adsorbates with the sillimanite (010) surface [34].

\section{Results and Discussion}

\subsection{Micro-Flotation}

Micro-flotation tests were conducted to show the flotation behavior of sillimanite and the depression of $\mathrm{Ca}^{2+}$ ions. The flotation results of sillimanite with increasing DAC concentration are shown in Figure 3. The flotation recovery of the sillimanite increased rapidly with increasing DAC concentration until $4.50 \times 10^{-4} \mathrm{M}$, and above that the recovery increased insignificantly. The maximum flotation recovery reached around $87 \%$ using a collector dosage of $7.21 \times 10^{-4} \mathrm{M}$.

Figure 4 describes the flotation responses of sillimanite as a function of $\mathrm{Ca}^{2+}$ ions with a concentration fixed at $\mathrm{pH}=7.0$, and the collector concentration was $4.50 \times 10^{-4} \mathrm{M}$. These results demonstrate that the flotation recovery of sillimanite decreased sharply as the concentration of $\mathrm{Ca}^{2+}$ ions increased from 0 to $1.00 \times 10^{-4} \mathrm{M}$, beyond which the flotation recovery of sillimanite reduced gradually and remained constant when $2.00 \times 10^{-4} \mathrm{M}$ of $\mathrm{Ca}^{2+}$ ions was dissolved prior to the test.

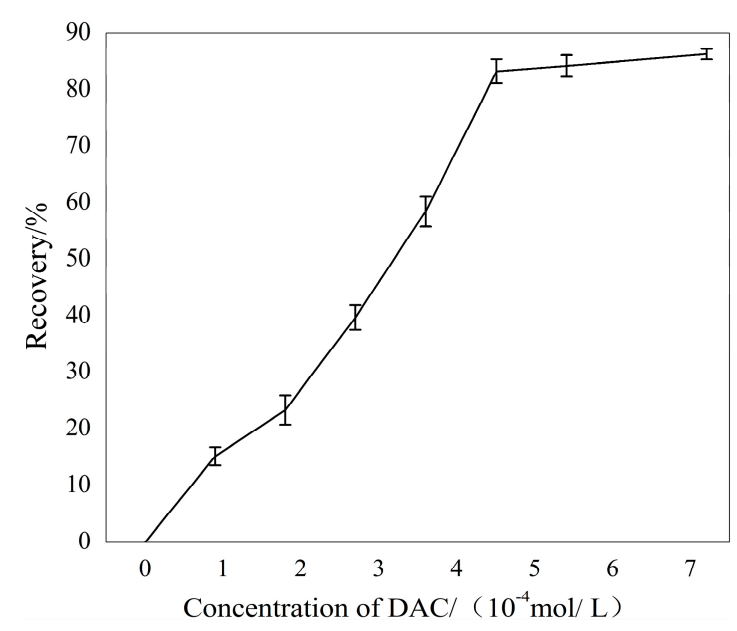

Figure 3. The flotation recovery of sillimanite as a function of dodecylammonium chloride (DAC) concentration at $\mathrm{pH}=7.0$.

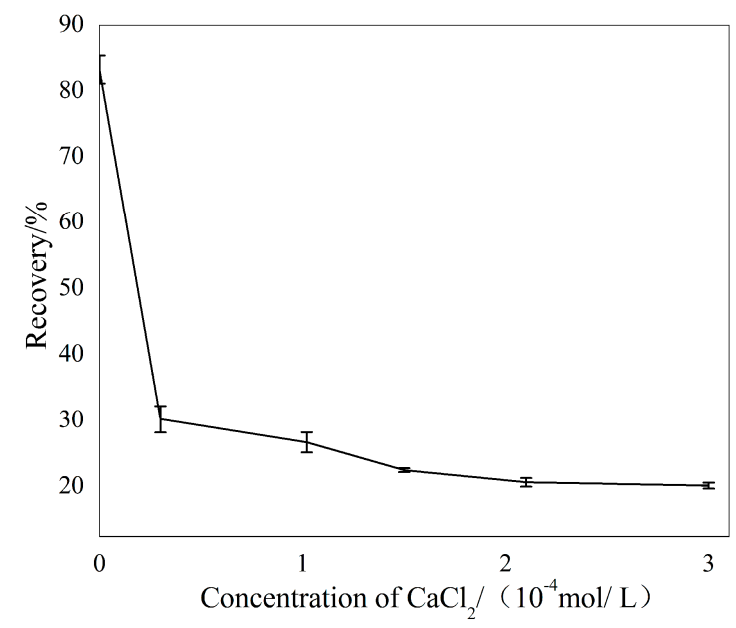

Figure 4. The flotation recovery of sillimanite as a function of $\mathrm{Ca}^{2+}$ ions concentration with $4.50 \times 10^{-4} \mathrm{M}$, $\mathrm{DAC}$ at $\mathrm{pH}=7.0$. 
The curves given in Figure 5 show the flotation recovery of sillimanite as a function of $\mathrm{pH}$ with and without $1.00 \times 10^{-4} \mathrm{M} \mathrm{Ca}^{2+}$ ions. Sillimanite showed a better floatability throughout the $\mathrm{pH}$ range of 2.0-9.0 without $\mathrm{Ca}^{2+}$ ions, and recovery was promoted as $\mathrm{pH}$ increased and reached $87.25 \%$ at $\mathrm{pH}=9.0$. In the presence of $\mathrm{Ca}^{2+}$ ions, the recovery of sillimanite increased with increasing $\mathrm{pH}$ and reached approximately $30.36 \%$ at $\mathrm{pH}=9.0$, which was less than $50 \%$ of the figure when $\mathrm{Ca}^{2+}$ ions were absent. It is obvious that the recovery of sillimanite was very low when $\mathrm{pH}$ values were less than 6.0, beyond which recovery increased rapidly.

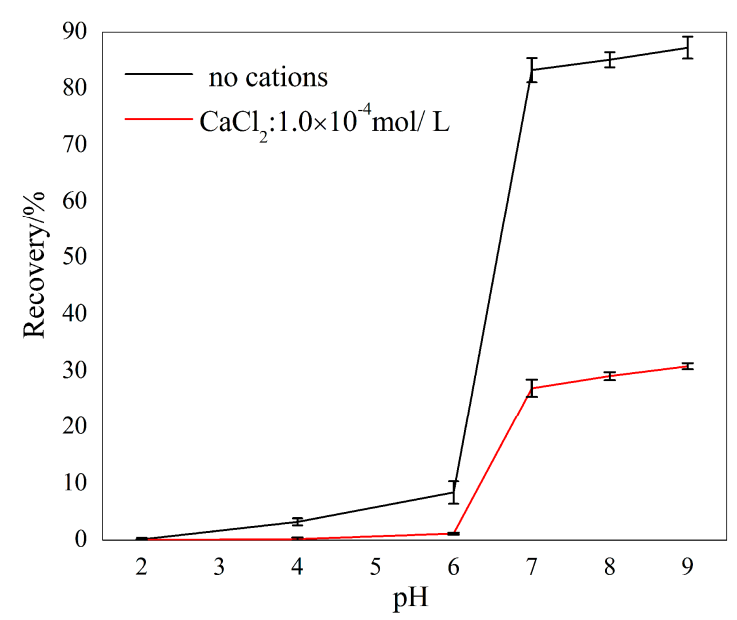

Figure 5. The flotation recovery of sillimanite as a function of $\mathrm{pH}$ with $4.50 \times 10^{-4} \mathrm{M} \mathrm{DAC}$.

\subsection{Zeta Potential Analyses}

The zeta potentials of sillimanite as a function of $\mathrm{pH}$ in the absence and presence of $1.00 \times 10^{-4} \mathrm{M}$ $\mathrm{Ca}^{2+}$ ions were measured, and the results are shown in Figure 6. In the absence of $\mathrm{Ca}^{2+}$ ions, the point of zero charge (PZC) of sillimanite occurred at $\mathrm{pH} 5.4$, when $\mathrm{pH}>5.4$, the charge of the mineral surface switched from positive to negative, and the cationic collector DAC could interact with sillimanite at this $\mathrm{pH}$ value. Compared to Figure 5, it can be concluded that the interaction between DAC and sillimanite appear to be governed well by electrostatic interactions in this condition, which agrees with results from other research [10]. In the presence of $\mathrm{Ca}^{2+}$ ions, the PZC of sillimanite showed a slight change, which shifted to 6.1. This behavior of zeta potential suggests that the $\mathrm{Ca}^{2+}$ ions are being adsorbed on the sillimanite surface $[6,13,15,35]$.

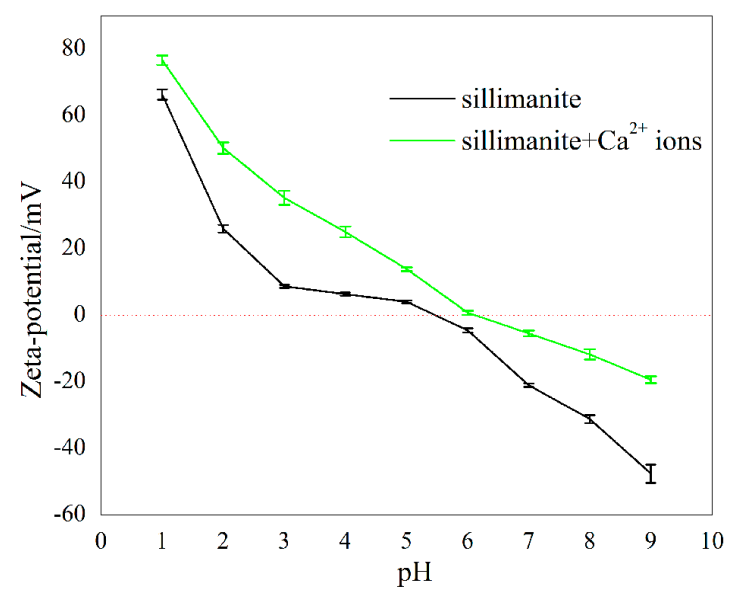

Figure 6. Zeta potentials of sillimanite mineral as a function of $\mathrm{pH}$ in the absence and presence of $\mathrm{Ca}^{2+}$ ions. 


\subsection{Solution Chemistry Analyses}

Species distribution diagrams of $\mathrm{Ca}^{2+}$ ions $\left(1.0 \times 10^{-4} \mathrm{M}\right)$ and DAC $\left(4.50 \times 10^{-4} \mathrm{M}\right)$ as a function of $\mathrm{pH}$ are shown in Figure 7. $\mathrm{Ca}^{2+}$ ions main exist as free ions throughout the $\mathrm{pH}$ range of 2.0-7.0, and the concentration of free ions decreased as $\mathrm{pH}$ increased. When $\mathrm{pH}$ levels were between 7.0 and 9.0, concentrations of the cation hydrolysis products $[\mathrm{CaOH}]^{+}$increased obviously, but $\mathrm{Ca}^{2+}$ ions still dominated in this $\mathrm{pH}$ range. In the $\mathrm{pH}$ range of $2.0-9.0,[\mathrm{CaOH}]^{+}$was found in an exceptionally small amount, 1000-fold less than $\mathrm{Ca}^{2+}$ ions, so $\mathrm{Ca}^{2+}$ ions acted as the only component of $\mathrm{Ca}$ species in further discussion. DAC existed mainly as $\mathrm{RNH}_{3}{ }^{+}$ions when $\mathrm{pH}<9.3$; when the $\mathrm{pH}$ was above five, concentrations of $\mathrm{RNH}_{2}$ (aq) increased as the $\mathrm{pH}$ increased, but far less than that of $\mathrm{RNH}_{3}{ }^{+}$ions as $\mathrm{pH} \leq 9$, hence only $\mathrm{RNH}_{3}{ }^{+}$ions were considered as a collector component in the present study.

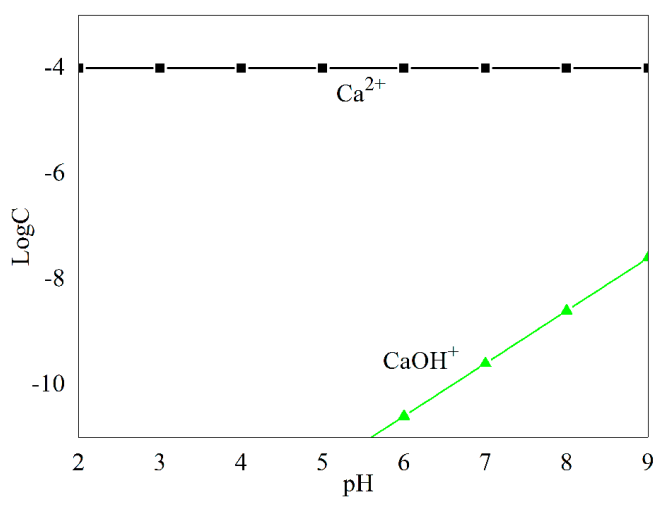

(a)

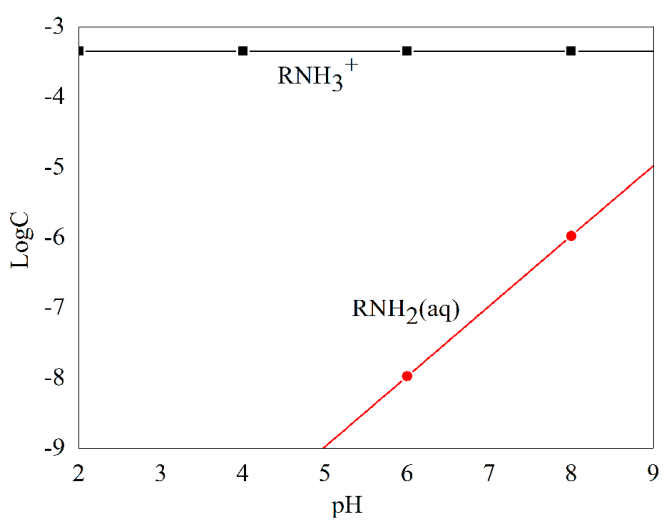

(b)

Figure 7. Species distribution diagrams of $1.00 \times 10^{-4} \mathrm{M} \mathrm{Ca}^{2+}$ ions (a) and $4.50 \times 10^{-4} \mathrm{M} \mathrm{DAC} \mathrm{(b)}$ as a function of $\mathrm{pH}$.

Based on the above analysis, this study found that $\mathrm{RNH}_{3}{ }^{+}$ions were adsorbed on sillimanite by electrostatic attraction. Under this condition, the Boltzmann factor gives the probability of finding an ions $i$ of charge $z_{i}$ e at a particular point with potential $\phi$, so that the distribution of ions in a potential field can be given by:

$$
C_{i}=C_{i 0} \cdot \exp \left(-z_{i} \cdot \phi F / R T\right)
$$

where $C_{i}$ is the concentration of $i$ at the point where the potential is $\phi ; C_{i 0}$ is the concentration of $i$ at the point where the potential is zero (out in the bulk solution); and $z_{i}$ is the valence of $i . F$ is the Faraday constant; $R$ is the gas constant; and $T$ is the absolute temperature $[10,36,37]$.

As an approximation, the potential of the sillimanite surface can be considered to vary with $\mathrm{pH}$ by:

$$
\phi=0.059\left(\mathrm{pH}_{\mathrm{PZC}}-\mathrm{pH}\right)
$$

where $\mathrm{pH}_{\mathrm{PZC}}$ is the $\mathrm{pH}$ value when the sillimanite surface charge is zero [10].

As can be seen in Figure 6, the PZC of sillimanite showed a slight change in the presence of $\mathrm{Ca}^{2+}$ ions, which shifted from 5.4 to 6.1. Concentrations of $\mathrm{RNH}_{3}{ }^{+}$ions in the sillimanite interface layer in the absence and presence of $\mathrm{Ca}^{2+}$ ions are shown in Table 2, with $C_{i 0}$ fixed at $4.50 \times 10^{-4} \mathrm{M}$.

In the absence of $\mathrm{Ca}^{2+}$ ions, the concentration of $\mathrm{RNH}_{3}{ }^{+}$ions in the sillimanite interface layer increased as the $\mathrm{pH}$ increased, when the $\mathrm{pH}$ was above six, the concentration of $\mathrm{RNH}_{3}{ }^{+}$ions in the sillimanite interface layer was higher than that of the bulk solution, and the recovery of sillimanite increased rapidly in this condition as shown in Figure 5. With the addition of $\mathrm{Ca}^{2+}$ ions, the concentration of $\mathrm{RNH}_{3}{ }^{+}$ions in the sillimanite interface layer reduced significantly, and the concentration of $\mathrm{RNH}_{3}{ }^{+}$ ions in the sillimanite interface layer was higher than that of the bulk solution when the $\mathrm{pH}$ was above seven. These results are coherent with the results of the micro-flotation experiments. 
Table 2. The concentration of $\mathrm{RNH}_{3}{ }^{+}$in the sillimanite interface layer in the absence and presence of $\mathrm{Ca}^{2+}$ ions. $C_{i}$ and $C_{i}{ }^{\prime}$ are the concentrations of $\mathrm{RNH}_{3}{ }^{+}$ions in the sillimanite interface layer without and with $\mathrm{Ca}^{2+}$ ions, respectively.

\begin{tabular}{ccccccccc}
\hline $\mathrm{pH}$ & 2 & 3 & 4 & 5 & 6 & 7 & 8 \\
\hline$C_{\boldsymbol{i}} \mathbf{( M )}$ & $1.82 \times 10^{-7}$ & $1.81 \times 10^{-6}$ & $1.80 \times 10^{-5}$ & $1.79 \times 10^{-4}$ & $1.79 \times 10^{-3}$ & $1.78 \times 10^{-2}$ & $1.77 \times 10^{-1}$ & 1.76 \\
$\boldsymbol{C}_{\boldsymbol{i}} / \boldsymbol{C}_{\boldsymbol{i} \mathbf{0}}$ & $4.04 \times 10^{-4}$ & $4.02 \times 10^{-3}$ & $4.01 \times 10^{-2}$ & $3.99 \times 10^{-1}$ & 3.97 & 39.52 & 393.41 \\
$C_{\boldsymbol{i}}{ }^{\prime}(\mathbf{M})$ & $3.65 \times 10^{-8}$ & $3.63 \times 10^{-7}$ & $3.62 \times 10^{-6}$ & $3.60 \times 10^{-5}$ & $3.58 \times 10^{-4}$ & $3.57 \times 10^{-3}$ & $3.55 \times 10^{-2}$ & $3.54 \times 10^{-1}$ \\
$C_{\boldsymbol{i}}^{\prime} / \boldsymbol{C}_{\boldsymbol{i} \mathbf{0}}$ & $8.11 \times 10^{-5}$ & $8.07 \times 10^{-4}$ & $8.04 \times 10^{-3}$ & $8.00 \times 10^{-2}$ & $7.96 \times 10^{-1}$ & 7.93 & 78.92 & 785.61 \\
\hline
\end{tabular}

\subsection{Molecular Dynamics Calculation Results}

Molecular dynamics simulation was performed to study the adsorption mode of adsorbates on the sillimanite surface, and to clarify the inhibition mechanism of $\mathrm{Ca}^{2+}$ ions on sillimanite at the molecular level.

The values of the interaction and binding energies of the adsorbates on the sillimanite (010) surface were calculated according to the Equations (1) and (2), and are listed in Table 3. The binding energy of the water molecule with the sillimanite (010) surface was $189.36 \mathrm{kcal} / \mathrm{mol}$, indicating that the water molecule can adsorb spontaneously on the sillimanite (010) surface, and the $E_{\mathrm{b}}\left(\mathrm{H}_{2} \mathrm{O}\right)$ was lower than that of other adsorbates, suggesting that other adsorbates could replace water on the sillimanite (010) surface $[6,29,31,38]$.

The optimized adsorption configurations are graphically illustrated in Figure 8, with values indicating the atomic distance in angstroms. It clearly shows that the $\mathrm{Ca}$ atom was closely bonded with the $\mathrm{O}$ atom in both $\mathrm{Ca}^{2+}$ and $\mathrm{Ca}^{2+}+\mathrm{RNH}_{3}{ }^{+}(\mathrm{CN})$ systems (Figure 8a,c), and the interatomic distance was $2.00 \AA$ and $2.16 \AA$, respectively, indicating that a chemistry bond between the Ca atom and surface $\mathrm{O}$ atom in the two systems may form. It is noted, that as the $\mathrm{Ca}^{2+}$ ions mainly interacted with $\mathrm{O}$ atoms on the sillimanite (010) surface, the occupancy of cations on the sillimanite (010) surface will rise as a consequence and the surface charge of the sillimanite will increase with the addition of $\mathrm{Ca}^{2+}$ ions, which corroborates with the zeta potential analysis.

The adsorption configurations of $\mathrm{N}\left(\mathrm{RNH}_{3}{ }^{+}\right)$and $\mathrm{CN}$ systems are presented in Figure 8b,c. It is worth noting that the adsorption process of $\mathrm{CN}$ system was conducted in two steps: the adsorption of $\mathrm{Ca}^{2+}$ ions on the sillimanite (010) surface was defined as the first step, with the later collector $\mathrm{RNH}_{3}{ }^{+}$ adsorbing on the inhibited sillimanite (010) surface as the second steps. The results in Figure 8b,c indicate that $\mathrm{RNH}_{3}{ }^{+}$mayinteract with the sillimanite (010) surface through electrostatic attraction in the absence and presence of $\mathrm{Ca}^{2+}$ ions, and the presence of $\mathrm{Ca}^{2+}$ ions decreases the interaction between $\mathrm{H}$ in the $\mathrm{RNH}_{3}{ }^{+}$and $\mathrm{O}$ on the sillimanite (010) surface. Therefore, $\mathrm{Ca}^{2+}$ ions and $\mathrm{RNH}_{3}{ }^{+}$may compete for adsorption on the sillimanite (010) surface through interacting with $\mathrm{O}$ atoms.

The binding energy of the sillimanite (010) surface with $\mathrm{RNH}_{3}{ }^{+}$in the absence and presence of $\mathrm{Ca}^{2+}$ ions was $424.56 \mathrm{kcal} / \mathrm{mol}$ and $395.55 \mathrm{kcal} / \mathrm{mol}$, respectively. Since the higher binding energy indicates stronger interactions or stable adsorption [20], this suggests that the combination of the sillimanite (010) surface with $\mathrm{RNH}_{3}{ }^{+}$is firmer than that with $\mathrm{CN}$. Therefore, it could be found that $\mathrm{Ca}^{2+}$ has an apparent depression on the adsorption of $\mathrm{RNH}_{3}{ }^{+}$on the sillimanite (010) surface, which is in line with the flotation results.

Table 3. The interaction and binding energies between adsorbates and the sillimanite (010) surface.

\begin{tabular}{ccccc}
\hline Adsorbate & $\mathbf{H}_{\mathbf{2}} \mathbf{O}$ & $\mathbf{C a}^{2+}$ & $\mathbf{R N H}_{3}{ }^{+} \mathbf{( N )}$ & $\mathbf{C a}^{2+}+\mathbf{R N H}_{3}{ }^{+}(\mathbf{C N})$ \\
\hline$E_{\mathrm{i}}(\mathrm{kcal} / \mathrm{mol})$ & -189.36 & -489.68 & -424.56 & -395.55 \\
\hline
\end{tabular}




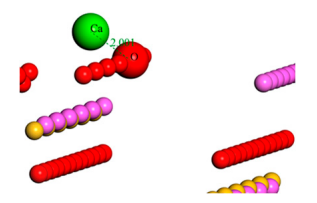

(a)

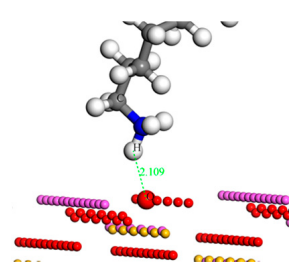

(b)

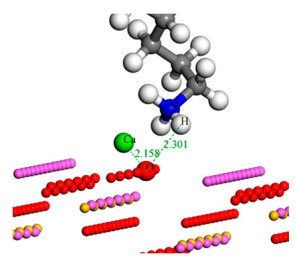

(c)

Figure 8. Optimized adsorption configurations of: (a) $\mathrm{Ca}^{2+}$; (b) $\mathrm{RNH}_{3}{ }^{+}(\mathrm{N})$; and (c) $\mathrm{Ca}^{2+}+\mathrm{RNH}_{3}{ }^{+}$ $(\mathrm{CN})$ on the sillimanite $(010)$ surface (atom color: green $=\mathrm{Ca}$, white $=\mathrm{H}$, gray $=\mathrm{C}$, blue $=\mathrm{N}$ ).

\section{Conclusions}

Micro-flotation tests achieved flotation recoveries of sillimanite in the presence of DAC, where the floatability of sillimanite was inhibited by adding $\mathrm{Ca}^{2+}$ ions. The maximum flotation recovery of sillimanite decreased from $87.25 \%$ to $30.36 \%$ at $\mathrm{pH}=9.0$ with $\mathrm{Ca}^{2+}$ ions. Zeta potential measurements results illustrated that sillimanite was positively charged below $\mathrm{pH}=5.4$ in water; however, the mineral became negatively charged at $\mathrm{pH}$ range of 6.1-10.0 in the presence of $\mathrm{Ca}^{2+}$ ions. Under these conditions, the concentration of $\mathrm{RNH}_{3}{ }^{+}$in the sillimanite interface layer was reduced with the addition of $\mathrm{Ca}^{2+}$ ions. The results of MD simulations indicated that $\mathrm{NH}_{3}{ }^{+}$interacted with the sillimanite (010) surface through electrostatic attraction, that $\mathrm{Ca}^{2+}$ ions possibly adsorbed on the sillimanite (010) surface through chemical interaction, and that the binding energy of $\mathrm{RNH}_{3}{ }^{+}$with the sillimanite (010) surface decreased in the presence of $\mathrm{Ca}^{2+}$ ions.

Acknowledgments: The authors would like to acknowledge the financial support for this work provided by "the Fundamental Research Funds for the Central Universities (WUT: 2016IVA048)" and Wuhan University of Technology.

Author Contributions: Zijie Ren, Huimin Gao and Fanfei Min conceived the project and designed the experiments; Zhijie Chen conducted a part of experiments and analyzed the data. Jia Lu and Junxun Jin performed a part of experiments. All authors participated in writing the manuscript.

Conflicts of Interest: The authors declare no conflict of interest.

\section{References}

1. Filippov, L.O.; Duverger, A.; Filippova, I.V.; Kasaini, H.; Thiry, J. Selective flotation of silicates and Ca-bearing minerals: The role of non-ionic reagent on cationic flotation. Min. Eng. 2012, 36, 314-323. [CrossRef]

2. Murty, C.; Murthy, Ch.V.R.; JaiSankar, N.; Manjeera, P.B.; Kumar, P. Operation and optimization of sillimanite beneficiation from beach sands. Int. J. Intell. Inf. Technol. 2013, 1, 347-355.

3. Murthy, V.A.N. Beneficiation of sillimanite by flotation. Int. J. Intell. Inf. Technol. 2013, 1, $24-28$.

4. Prabhakar, S.; Bhaskar Raju, G.; Subba Rao, S. Beneficiation of sillimanite by column flotation-A pilot scale study. Int. J. Min. Process. 2006, 81, 159-165. [CrossRef]

5. Laxmia, T.; Raob, R.B. Upgradation of sillimanite by using advanced air cyclone classifier. Turk. J. Eng. 2013, $3,46-52$.

6. Jin, J.; Gao, H.; Chen, X.; Peng, Y.; Min, F. The flotation of aluminosilicate polymorphic minerals with anionic and cationic collectors. Min. Eng. 2016, 99, 123-132. [CrossRef]

7. Prabhakar, S.; Hanumantha Rao, K.; Forsling, W. Dissolution of wollastonite and its flotation and surface interactions with tallow-1,3-diaminopropane (duomeen T). Min. Eng. 2005, 18, 691-700. [CrossRef]

8. You, C.; Zeng, X. The research of sillimanite flotation collection selection. J. Wuhan Univ. Technol. 1990, 3, 52-58.

9. Demir, C.; Bentli, I.; Gülgönül, I.; Çelik, M.S. Effects of bivalent salts on the flotation separation of Na-feldspar from K-feldspar. Miner. Eng. 2003, 16, 551-554. [CrossRef]

10. Fuerstenaua, D.W. Zeta potentials in the flotation of oxide and silicate minerals. Adv. Colloid Interface Sci. 2005, 114, 9-26. [CrossRef]

11. Yu, F.; Wang, Y.; Wang, J.; Xie, Z. Investigation on different behavior and mechanism of Ca (II) and Fe (III) adsorption on spodumene surface. Phys. Probl. Min. Process. 2014, 50, 535-550. 
12. Yu, F.; Wang, Y.; Wang, J.; Xie, Z.; Zhang, L. First-principle investigation on mechanism of Ca ion activating flotation of spodumene. Rare Met. 2014, 33, 358-362. [CrossRef]

13. Liu, W.; Zhang, S.; Wang, W.; Zhang, J.; Yan, W.; Deng, J.; Feng, Q.; Huang, Y. The effects of Ca (II) and $\mathrm{Mg}$ (II) ions on the flotation of spodumene using NaOL. Miner. Eng. 2015, 79, 40-46. [CrossRef]

14. Li, Y.; Lei, D.; Xu, S. Effect of metal ions in pulp on flotation separation of sillimanite from quartz. J. Chin. Ceram. Soc. 2002, 30, 362-364.

15. Lu, J.; Gao, H.; Jin, J.; Cen, D.; Ren, Z. Effect and mechanism of calcium ion on flotation of andalusite. Chin. J. Nonferr. Met. 2016, 26, 1311-1315.

16. El-Salmawy, M.S.; Nakahiro, Y.; Wakamatsu, T. The role of alkaline earth cations in flotation separation of quartz from feldspar. Miner. Eng. 1993, 6, 1231-1243. [CrossRef]

17. Burdukova, E.; Van Leerdam, G.C.; Prins, F.E.; Smeink, R.G.; Bradshaw, D.J.; Laskowski, J.S. Effect of calcium ions on the adsorption of CMC onto the basal planes of New York talc-A ToF-SIMS study. Miner. Eng. 2008, 21, 1020-1025. [CrossRef]

18. Han, Y.; Liu, W.; Chen, J. DFT simulation of the adsorption of sodium silicate species on kaolinite surfaces. Appl. Surf. Sci. 2016, 370, 403-409. [CrossRef]

19. Demichelis, R.; Civalleri, B.; D'Arco, P.; Dovesi, R. Performance of 12 DFT functionals in the study of crystal systems: $\mathrm{Al}_{2} \mathrm{SiO}_{5}$ orthosilicates and $\mathrm{Al}$ hydroxides as a case study. Int. J. Quantum Chem. 2010, 110, 2260-2273. [CrossRef]

20. Jiang, Y.; Li, X. The theoretical study on the efficiencies of 2-[tris(hyroxycarbamoyl) methyl] carboxylic acids as chelating agents in flotation separation of diaspore and aluminosilicates. Sep. Purif. Technol. 2013, 104, 114-120. [CrossRef]

21. Gocmez, H. The interaction of organic dispersant with alumina: A molecular modelling approach. Ceram. Int. 2006, 32, 521-525. [CrossRef]

22. Qiang, L.; Li, Z.; Zhao, T.; Zhong, S.; Wang, H.; Cui, X. Atomic-scale interactions of the interface between chitosan and $\mathrm{Fe}_{3} \mathrm{O}_{4}$. Colloids Surf. A 2013, 419, 125-132. [CrossRef]

23. Guide, C.U. Force Field-Based Simulations; Molecular Simulations Inc.: San Diego, CA, USA, 1997.

24. Ji, Y.; Wang, F.; Duan, L.; Zhang, F.; Gong, X. Effect of temperature on the adsorption of sulfanilamide onto aluminum oxide and its molecular dynamics simulations. Appl. Surf. Sci. 2013, 285, 403-408. [CrossRef]

25. Bu, H.; Cao, M.; Gao, Y.; Huang, H. Synergic effect of sodium oleate (NaOL) and benzohydroxamic acid (BHA) on flotation of wolframite. Phys. Probl. Min. Process. 2017, 53, 82-93.

26. Rai, B.; Sathish, P.; Tanwar, J.; Moon, K.S.; Fuerstenau, D.W. A molecular dynamics study of the interaction of oleate and dodecylammonium chloride surfactants with complex aluminosilicate minerals. J. Colloid Interface Sci. 2011, 362, 510-516. [CrossRef] [PubMed]

27. Prathab, B.; Subramanian, V.; Aminabhavi, T.M. Molecular dynamics simulations to investigate polymer-polymer and polymer-metal oxide interactions. Polymer 2007, 48, 409-416. [CrossRef]

28. Mi, H.; Xiao, G.; Chen, X. Theoretical evaluation of corrosion inhibition performance of three antipyrine compounds. Comput. Theor. Chem. 2015, 1072, 7-14. [CrossRef]

29. Pradip; Rai, B. Molecular modeling and rational design of flotation reagents. Int. J. Miner. Process. 2003, 72, 95-110. [CrossRef]

30. Hu, Y.; Gao, Z.; Sun, W.; Liu, X. Anisotropic surface energies and adsorption behaviors of scheelite crystal. Colloids Surf. A 2012, 415, 439-448. [CrossRef]

31. Pradip; Rai, B.; Rao, T.K.; Krishnamurthy, S.; Vetrivel, R.; Mielczarski, J.; Cases, J.M. Molecular modeling of interactions of diphosphonic acid based surfactants with calcium minerals. Langmuir 2002, 18, 932-940. [CrossRef]

32. Xu, Y.; Liu, Y.; Liu, G. Molecular dynamics simulation of primary ammonium ions with different alkyl chains on the muscovite (001) surface. Int. J. Miner. Process. 2015, 145, 48-56. [CrossRef]

33. Zhang, H.; Lu, X.; Leng, Y.; Watari, F.; Weng, J.; Feng, B.; Qu, S. Effects of aqueous environment and surface defects on Arg-Gly-Asp peptide adsorption on titanium oxide surfaces investigated by molecular dynamics simulation. J. Biomed. Mater. Res. 2011, 96, 466-476. [CrossRef] [PubMed]

34. Xu, L.; Wu, H.; Dong, F.; Wang, L.; Wang, Z.; Xiao, J. Flotation and adsorption of mixed cationic/anionic collectors on muscovite mica. Miner. Eng. 2013,41,41-45. [CrossRef]

35. Jin, J.; Gao, H.; Ren, Z.; Chen, Z. The flotation of kyanite and sillimanite with sodium oleate as the collector. Minerals 2016, 6, 90. [CrossRef] 
36. Sun, C.; Yin, W. Flotation Principles of Silicate Minerals; Science Press: Beijing, China, 2001; pp. $216-223$.

37. Wang, B.; Peng, Y. The effect of saline water on mineral flotation-A critical review. Miner. Eng. 2014, 66, 13-24. [CrossRef]

38. Zhu, Y.; Luo, B.; Sun, C.; Liu, J.; Sun, H.; Li, Y.; Han, Y. Density functional theory study of $\alpha$-Bromolauric acid adsorption on the $\alpha$-quartz (101) surface. Miner. Eng. 2016, 92, 72-77. [CrossRef] 